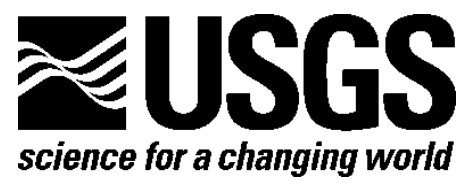

\title{
Histograms Showing Variations in Oil Yield, Water Yield, and Specific Gravity of Oil from Fischer Assay Analyses of Oil-Shale Drill Cores and Cuttings from the Piceance Basin, Northwestern Colorado
}

By John D. Dietrich, Michael E. Brownfield, Ronald C. Johnson, and Tracey J. Mercier

Open-File Report 2014-1057

U.S. Department of the Interior

U.S. Geological Survey 


\section{U.S. Department of the Interior \\ SALLY JEWELL, Secretary}

\section{U.S. Geological Survey \\ Suzette M. Kimball, Acting Director}

U.S. Geological Survey, Reston, Virginia: 2014

For more information on the USGS - the Federal source for science about the Earth, its natural and living resources, natural hazards, and the environment-visit http://www.usgs.gov or call 1-888-ASK-USGS

For an overview of USGS information products, including maps, imagery, and publications, visit $h$ ttp://www.usgs.gov/pubprod

To order this and other USGS information products, visit $h$ ttp://store.usgs.gov

Any use of trade, firm, or product names is for descriptive purposes only and does not imply endorsement by the U.S. Government.

Although this information product, for the most part, is in the public domain, it also may contain copyrighted materials as noted in the text. Permission to reproduce copyrighted items must be secured from the copyright owner.

Suggested citation:

Dietrich, J.D., Brownfield, M.E., Johnson, R.C., and Mercier, T.J., 2014, Histograms showing variations in oil yield, water yield, and specific gravity of oil from Fischer assay analyses of oil-shale drill cores and cuttings from the Piceance Basin, northwestern Colorado: U.S. Geological Survey Open-File Report 2014-1057, 12 p., http://dx.doi.org/10.3133/ofr20141057.

ISSN 2331-1258 (online) 


\section{Contents}

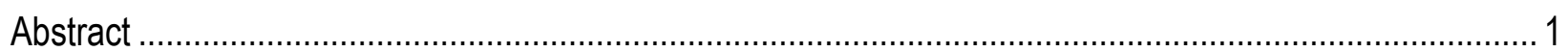

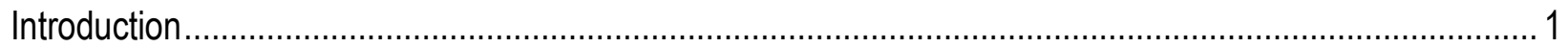

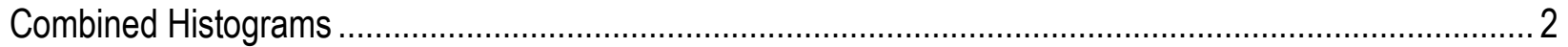

Shale Oil-Yield and Water-Yield Histograms............................................................................... 2

Shale Oil-Yield and Specific-Gravity Histograms ........................................................................... 3

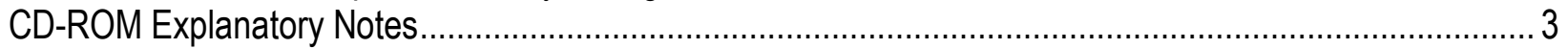

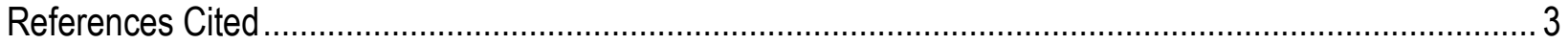

\section{Figures}

Figure 1. Map showing extent of Uinta, Piceance, and Greater Green River Basins and approximate extent of oil shale in the Green River Formation, Wyoming, Colorado, and Utah

Figure 2. West-to-east cross section through the Piceance Basin, the Douglas Creek arch, and the eastern part of the Uinta Basin, Colorado and Utah, showing member subdivisions, stages of Lake Uinta, and rich and lean zones

Figure 3. Map showing locations of oil-shale boreholes, as well as distribution of the Mesaverde Formation (and Group) and the Wasatch, Green River, and Uinta Formations in the Piceance Basin, northwestern Colorado

Figure 4. Example histogram plot showing Fischer assay oil-yield and water-yield data in gallons per ton for borehole $\mathrm{C} 0537$ in the Piceance Basin, northwestern Colorado

Figure 5. Example histogram plot showing Fischer assay oil-yield data in gallons per ton and oil specific gravity for borehole c0537 in the Piceance Basin, northwestern Colorado.

\section{Tables}

Table 1. Boreholes and stratigraphic tops in the Piceance Basin, northwestern Colorado, or also available on CD-ROM that can be requested from $h$ ttp://pubs. usgs.gov/of/2014/1057. link

Table 2. Names and definitions for the column headers for the Colorado oil-shale borehole information spreadsheet (table 1) 12

Table 3. Names and definitions for the column headers in the Fischer assay data spreadsheets 12 


\title{
Histograms Showing Variations in Oil Yield, Water Yield, and Specific Gravity of Oil from Fischer Assay Analyses of Oil-Shale Drill Cores and Cuttings from the Piceance Basin, Northwestern Colorado
}

\author{
By John D. Dietrich, Michael E. Brownfield, Ronald C. Johnson, and Tracey J. Mercier
}

\begin{abstract}
Recent studies indicate that the Piceance Basin in northwestern Colorado contains over 1.5 trillion barrels of oil in place, making the basin the largest known oil-shale deposit in the world. Previously published histograms display oil-yield variations with depth and widely correlate rich and lean oil-shale beds and zones throughout the basin. Histograms in this report display oil-yield data plotted alongside either water-yield or oil specific-gravity data. Fischer assay analyses of core and cutting samples collected from exploration drill holes penetrating the Eocene Green River Formation in the Piceance Basin can aid in determining the origins of those deposits, as well as estimating the amount of organic matter, halite, nahcolite, and water-bearing minerals. This report focuses only on the oil yield plotted against water yield and oil specific gravity.
\end{abstract}

\section{Introduction}

The Green River Formation in the Piceance Basin of northwestern Colorado (fig. 1) was deposited in Lake Uinta during early to middle Eocene time, with the richest oil-shale deposits (Johnson and others, 2010) in the Garden Gulch and Parachute Creek Members (fig. 2). From this area, rich in oil shale, data were collected and preserved for use by researchers and industry in anticipation of a time when Green River oil-shale deposits would become an economically practical alternate source of fossil energy. For several decades, the U.S. Geological Survey (USGS) has collected core, cuttings and other subsurface data from boreholes drilled to evaluate these oil-shale deposits (Smith and others, 1972; Beard and others, 1974; Brownfield and others, 2010). Types of collected data include (1) Fischer (shale oil) assay analyses (American Society for Testing and Materials [ASTM], 1984) on cores and cuttings from rotary-drilled holes; (2) geophysical and lithologic logs of drill holes; (3) chemical, water-quality, and X-ray diffraction analyses; as well as (4) rock-mechanics data. Dyni (1998), in cooperation with the U.S. Department of Energy, published original Fischer assay data on 737 oil-shale exploration holes, containing about 298,500 assays in text format. Most of the Fischer assays on oil-shale samples were conducted by the U.S. Bureau of Mines (USBM) laboratory in Laramie, Wyoming. From the late 1940s to the early 1980s, the USBM analyzed core splits and drill cuttings from holes drilled in the Green River Formation oil-shale deposits in Colorado, Utah, and Wyoming; holes 
were drilled both by Federal agencies and private industry. In addition, some Fischer assay analyses also were conducted by private laboratories. Dyni's original publication recently was updated with additional Fischer assay data (Mercier and others, 2010). Figure 3 shows the general locations of those drill holes in northwestern Colorado. Each drill hole was assigned a unique 4-digit number preceded by "c" for Colorado (for example, c0001). Rotary-drilled holes are identified by the suffix " $R$ " following the USGS drill-hole number, whereas core holes have no "R" suffix. Rotary holes produce chips whereas core holes produce continuous samples. In addition, surface sections are noted with the suffix " $\mathrm{S}$ " following the unique identifier. Much of the data was obtained from energy companies that drilled exploratory holes on private or leased oil-shale lands in the region. Those companies generously donated Fischer assay and other kinds of analytical data as well as drill cores and cutting samples, which are being stored by the USGS. Fischer assay data from that database were used to construct the histograms presented here (see Fischer Assay spreadsheets at http://pubs.usgs.gov/of/2014/1057). Location data for 1,042 oil shale drill holes and surface sections are listed in table 1. The abbreviations and other details of location information for the drill holes and for the Fischer assay data used to create the histogram plots are provided here (tables 2 and 3), modified after Self and others (2010; chapter 7 of USGS digital data report DDS-69-Y, also available at $h t t p: / / p u b s . u s g s . g o v / d d s / d d s-069 / d d s-069-$ y/REPORTS/69_Y_CH_7.pdf, accessed January 29, 2013).

\section{Combined Histograms}

Fischer assay data are presented graphically on histogram plots with two variables charted against depth on a single graph. Two types of these combined histograms are presented here, one with shale oil yield and water yield together, and one with shale oil yield and oil specific gravity. These plots originally were created in Grapher 7 (Golden Software, Inc., Golden, Colo., 2013) using the "Step Plot" feature in accessing data contained in Excel spreadsheets. Due to restrictions on spreadsheet size in Grapher 7, a single original Excel spreadsheet with all of the data had to be divided into seven smaller Excel spreadsheets (CO_Oil_Shale_Assays_1-100.xls, CO_Oil_Shale_Assays_101-200.xls, and so forth, in sequence). These spreadsheets are included in the "Fischer Assay spreadsheets" folder at http://pubs.usgs.gov/of/2014/1057. Grapher files (example, c0001.grf) were then exported in a Portable Document Format (PDF) and modified in Adobe Illustrator, where they were scaled vertically to $1 \mathrm{in} .=50 \mathrm{ft}$ and exported once again in PDF format (example, c0001.pdf, found in the "Histograms" folder). The assay data also are presented in database format (see “CO_Oil_Shale_Assays.mdb" file at http://pubs.usgs.gov/of/2014/1057.) Histograms of drill holes with two separate analyses are labeled with an "A" or "B" suffix.

\section{Shale Oil-Yield and Water-Yield Histograms}

Figure 4 illustrates an example of part of the oil shale oil-yield/water-yield histogram plot for one of the boreholes in the histogram folder. The vertical axis indicates the sample depth in feet below ground surface. The left-side horizontal axis of the graph indicates shale oil-yield values in gallons per ton (gpt) and ranges from 0 to 100; oil sample values are indicated by the red line. On the right side of the graph, the horizontal axis indicates water-yield values in gpt and ranges from 0 to 25; sampled water values are traced by the blue line. The vertical line separating shale oil yield from specific gravity is labeled " 0 ." In order to present continuous plots, depth intervals without analysis are plotted along the " 0 " line. 


\section{Shale Oil-Yield and Specific Gravity Histograms}

Figure 5 is an example of part of the oil shale oil-yield/specific-gravity histogram plot for one of the boreholes in the histogram folder. The vertical axis indicates sample depth in feet below ground surface. The horizontal axis on the left side of the graph indicates shale oil-yield values in gpt (same trace as figure 4) and ranges from 0 to 100; sample values are shown by the red line. On the right side of the graph, the horizontal axis indicates specific-gravity values and varies from 0.85 to 1.0 ; sample values there are indicated by the black line. The vertical line separating shale oil yield from specific gravity indicates "No Data." In order to present continuous plots, depth intervals without analysis are plotted along the "No Data" line.

\section{CD-ROM Explanatory Notes}

In addition to complete text (including figures), the CD-ROM, which can be requested from http://pubs.usgs.gov/of/2014/1057, contains material that would otherwise be cumbersome and presents table 1 (lengthy listing of relevant Colorado borehole locations, surface sections, and stratigraphic information), supporting spreadsheets (in Excel format) and database-format (.mdb) compilation from the Fischer assays, and the two sets of histograms (oil yield with water yield, and oil yield with oil specific gravity, each pair charted against depth, in the Histograms folder). For further information, see various chapters of a composite report on Piceance Basin oil-shale resources (U.S. Geological Survey Oil Shale Assessment Team, 2010).

Due to plotting limitations and size of the data set as previously noted, Fischer assay data (within the Fischer Assay spreadsheets folder) are presented in spreadsheet form in seven Microsoft Excel spreadsheets containing oil-shale results,. A Microsoft Access database (CO_Oil_Shale_Assays.mdb) contains Fischer assay records from the original laboratory reports. In a few cases, analyses were taken on separate samples from the same drill hole; those data are labeled with an "A" or "B" suffix following the drill-hole number. Where samples were not analyzed, the Fischer assay data fields are represented by zero values to allow for continuous histogram traces.

\section{References Cited}

American Society for Testing Materials [ASTM], 1984, Standard test method for oil shale, Designation D-388-80, in Annual Book of ASTM Standards: West Conshohocken, Penn., ASTM International, p. 513-525.

Beard, T.N., Tait, D.B., and Smith, J.H., 1974, Nahcolite and dawsonite resources in the Green River Formation, Piceance Basin, in Murray, D.K., ed., Energy resources of the Piceance Creek Basin, Colorado, Field Conference, $25^{\text {th }}$, Guidebook: Denver, Rocky Mountain Association of Geologists, p. 101-109.

Brownfield, M.E., Mercier, T.J., Johnson, R.C., and Self, J.G., 2010, Nahcolite resources in the Green River Formation, Piceance Basin, Colorado, chap. 2, of U.S. Geological Survey Oil Shale Assessment Team, Oil shale and nahcolite resources of the Piceance Basin, Colorado: U.S. Geological Survey Digital Data Series [DDS]-69-Y, 51 p. Available on CD-ROM and online at http://pubs.usgs.gov/dds/dds-069/dds-069-y/REPORTS/69_Y_CH_2.pdf/.

Cashion, W.B., and Donnell, J.R., 1972, Chart showing correlation of selected key units in the organic-rich sequence of the Green River Formation, Piceance Creek Basin, Colorado, and Uinta Basin, Utah: U.S. Geological Survey Oil and Gas Investigations Chart OC-65, not paginated. 
Dyni, J.D., 1998, Fischer assays of oil-shale drill cores and rotary cuttings from the Piceance Creek Basin, Colorado: U.S. Geological Survey Open-File Report 98-483. Available on CDROM, not paginated.

Golden Software, Inc., 2013, Grapher 7 software package: Golden, Colo., Golden Software, Inc., version 7 [2-D and 3-D technical graphing package], accessed May 20, 2013, at http://www.goldensoftware.com.

Johnson, R.C., 1985, Early Cenozoic history of the Uinta and Piceance Creek basins, Utah and Colorado, with special reference to the development of Eocene Lake Uinta, in Flores, R.M., and Kaplan, S.S., eds., Cenozoic paleogeography of the west-central United States-Rocky Mountain Paleography, Symposium 3: Society of Economic Paleontologists and Mineralogists, Rocky Mountain Section, p. 247-276.

Johnson, R.C., 2012, The systematic geologic mapping program and a quadrangle-by-quadrangle analysis of time-stratigraphic relations within oil shale-bearing rocks of the Piceance Basin, western Colorado: U.S. Geological Survey Scientific Investigations Report 2012-5041, 28 p., 2 pls., CD-ROM. Also available online at http://pubs.usgs.gov/sir/2012/5041/.

Johnson R.C., Mercier T.J., Brownfield, M.E., Pantea, M.P., and Self, J.G., 2010, An assessment of in-place oil shale resources in the Green River Formation, Piceance Basin, Colorado, chap. 1, of U.S. Geological Survey Oil Shale Assessment Team, Oil shale and nahcolite resources of the Piceance Basin, Colorado: U.S. Geological Survey Digital Data Series [DDS]-69-Y, 187 p. Available online at http://pubs.usgs.gov/dds/dds-069/dds-069-y/REPORTS/69_Y_CH_1.pdf/. Also available on CD-ROM.

Mercier, T.J., Brownfield, M.E., and Johnson, R.C., 2010, Methodology for calculating oil shale and nahcolite resources for the Piceance Basin, chap. 3, of U.S. Geological Survey Oil Shale Assessment Team, Oil shale and nahcolite resources of the Piceance Basin, Colorado: U.S. Geological Survey Digital Data Series [DDS]-69-Y, 61 p. Available online at http://pubs.usgs.gov/dds/dds-069/dds-069-y/REPORTS/69_Y_CH_3.pdf/. Also available on CD-ROM.

Mercier, T.J., and Johnson, R.C., 2012, Isopach and isoresource maps for oil shale deposits in the Eocene Green River Formation for the combined Uinta and Piceance Basins, Utah and Colorado: U.S. Geological Survey Scientific Investigations Report 2012-5076, 86 p., 1 pl. Also available at http://pubs.usgs.gov/sir/2012/5076/.

Self, J.G., Brownfield, M.E., Johnson, R.C., and Mercier, T.J., 2010, Fischer assay histograms of oil shale drill cores and cuttings from the Piceance Basin, northwestern Colorado, chap. 7 of U.S. Geological Survey Oil Shale Assessment Team, Oil shale and nahcolite resources of the Piceance Basin, Colorado: U.S. Geological Survey Digital Data Series [DDS]-69-Y, 9 p. Available at http://pubs.usgs.gov/dds/dds-069/dds-069-y/REPORTS/69_Y_CH_7.pdf/.

Smith, J.W., Beard, T.N., and Wade, P.M., 1972, Estimating nahcolite and dawsonite content of Colorado oil shale from oil-yield assay data: U.S. Bureau of Mines, Report of Investigations 7689, $24 \mathrm{p}$.

U.S. Geological Survey Oil Shale Assessment Team, 2010, Oil shale and nahcolite resources of the Piceance Basin, Colorado: U.S. Geological Survey Digital Data Series DS-69-Y, 7 chaps., paginated by chapter, available on CD-ROM and online at http://pubs.usgs.gov/dds/dds069/dds-069-y/. 


\section{Figures}

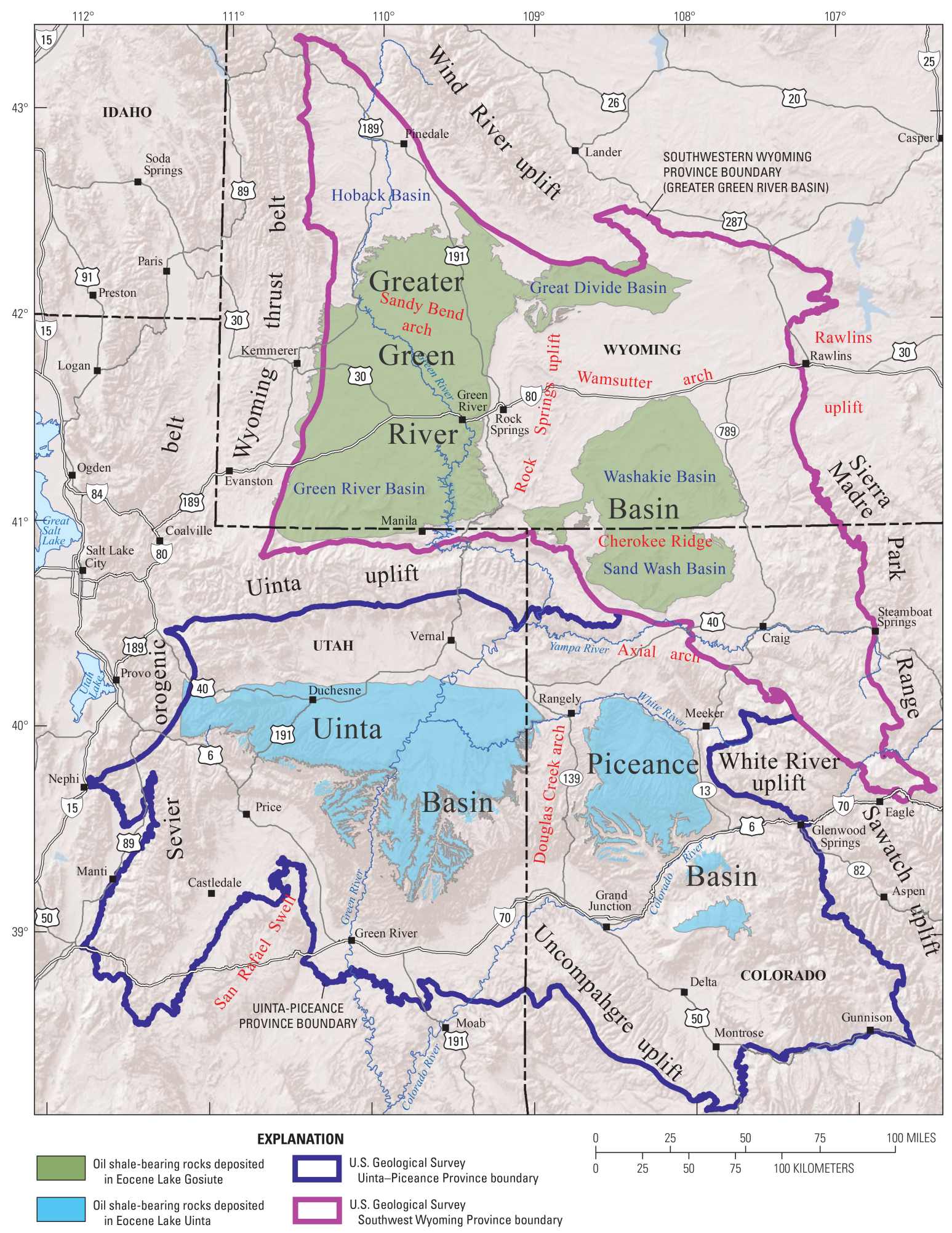

Figure 1. Extent of Uinta, Piceance, and Greater Green River Basins, and approximate extent of oil shale in the Green River Formation. Modified after Mercier and Johnson (2012). 


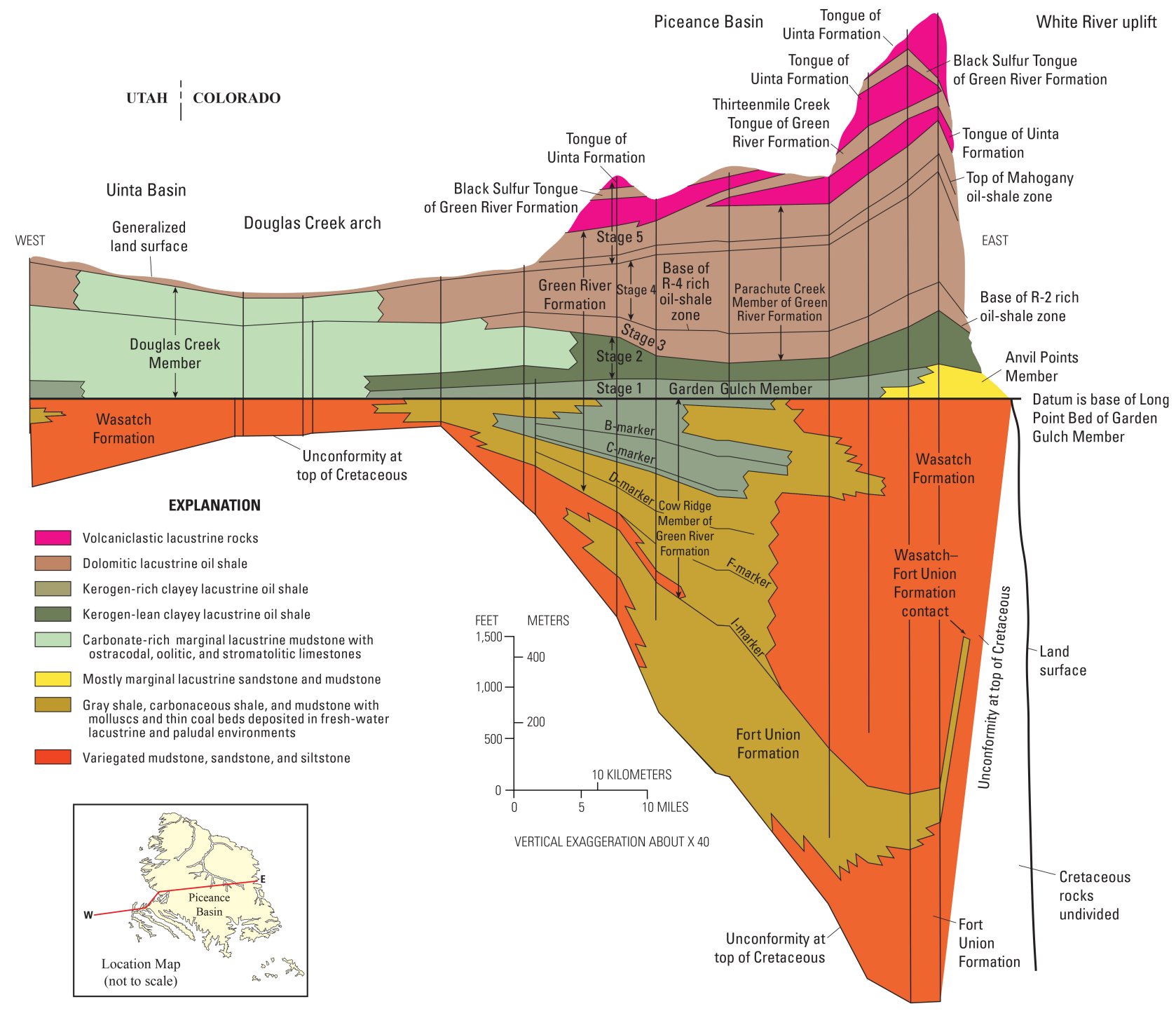

Figure 2. West-east cross section through the Piceance Basin, the Douglas Creek arch, and the eastern part of the Uinta Basin showing member subdivisions, stages of Lake Uinta as defined by Johnson (1985) and some of the rich and lean zones defined by Cashion and Donnell (1972). Modified after Johnson (2012). 


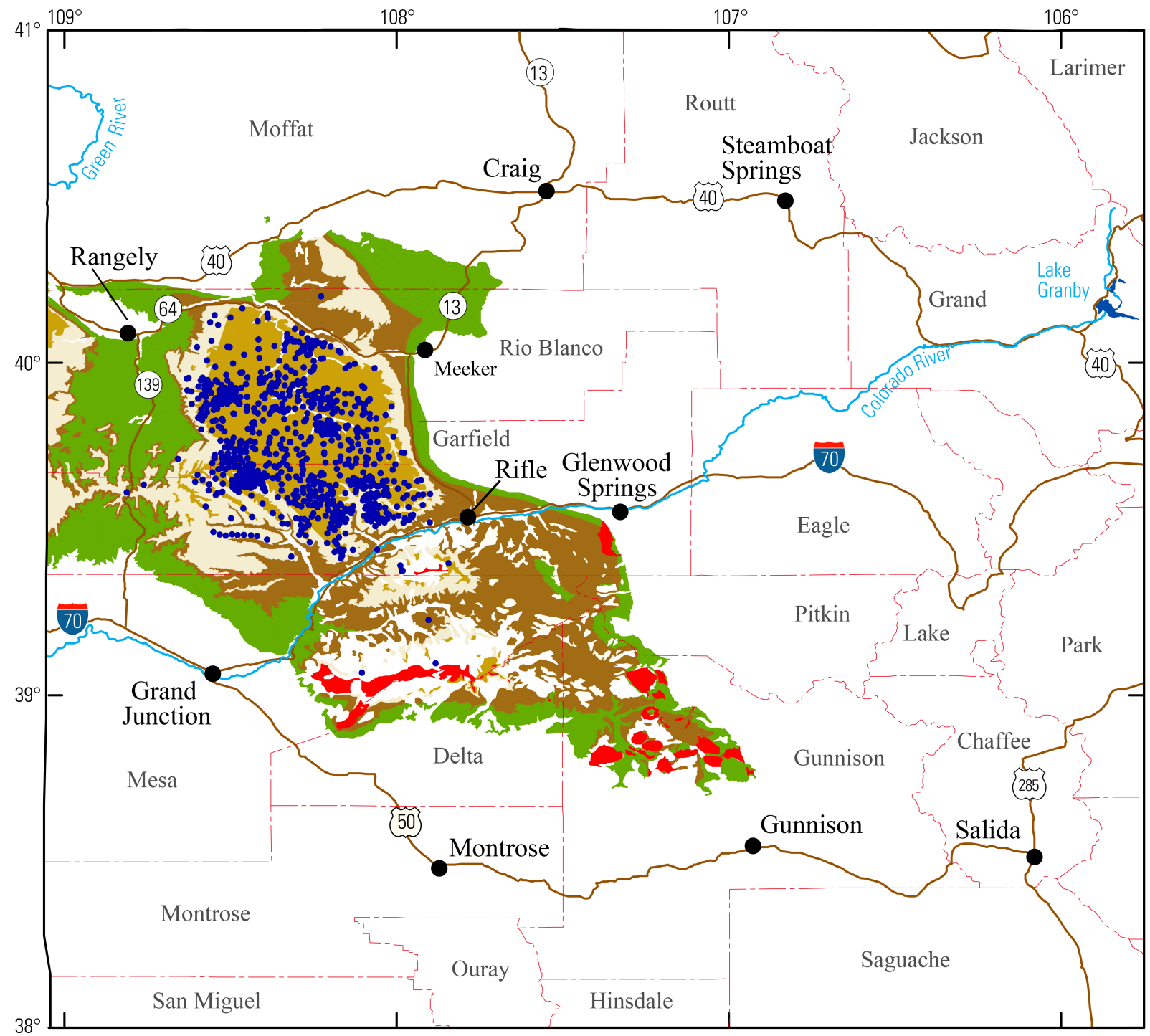

EXPLANATION

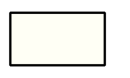

Undivided Quaternary, Tertiary, Mesozoic, and Paleozoic rocks TERTIARY

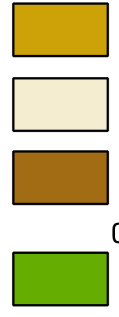

Uinta Formation and undivided Tertiary rocks

Green River Formation

Wasatch Formation and undivided lower Tertiary rocks CRETACEOUS

Mesaverde Fm. and Mesaverde Group coal-bearing rocks
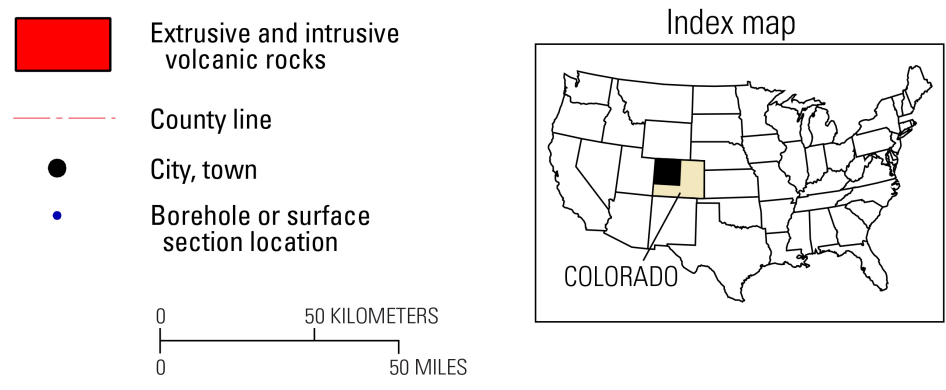

Figure 3. Locations of oil-shale boreholes, as well as the distribution of the Mesaverde Formation (or Group) and the Wasatch, Green River, and Uinta Formations in the Piceance Basin, northwestern Colorado. Modified after Johnson and others (2010). 


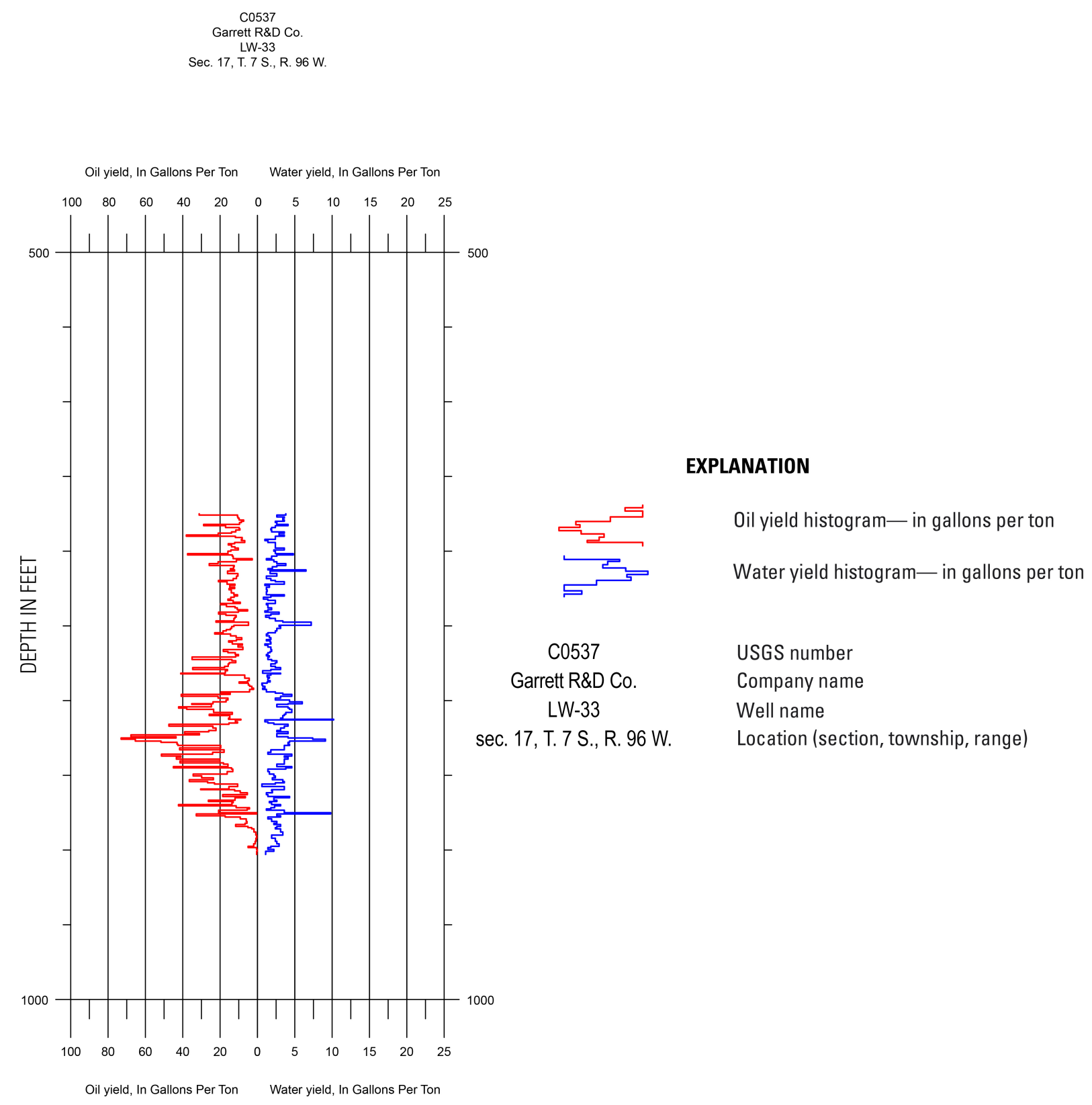

Figure 4. Example histogram plot showing Fischer assay oil-yield and water-yield results in gallons per ton for borehole c0537 in the Piceance Basin, northwestern Colorado, plotted against depth. 


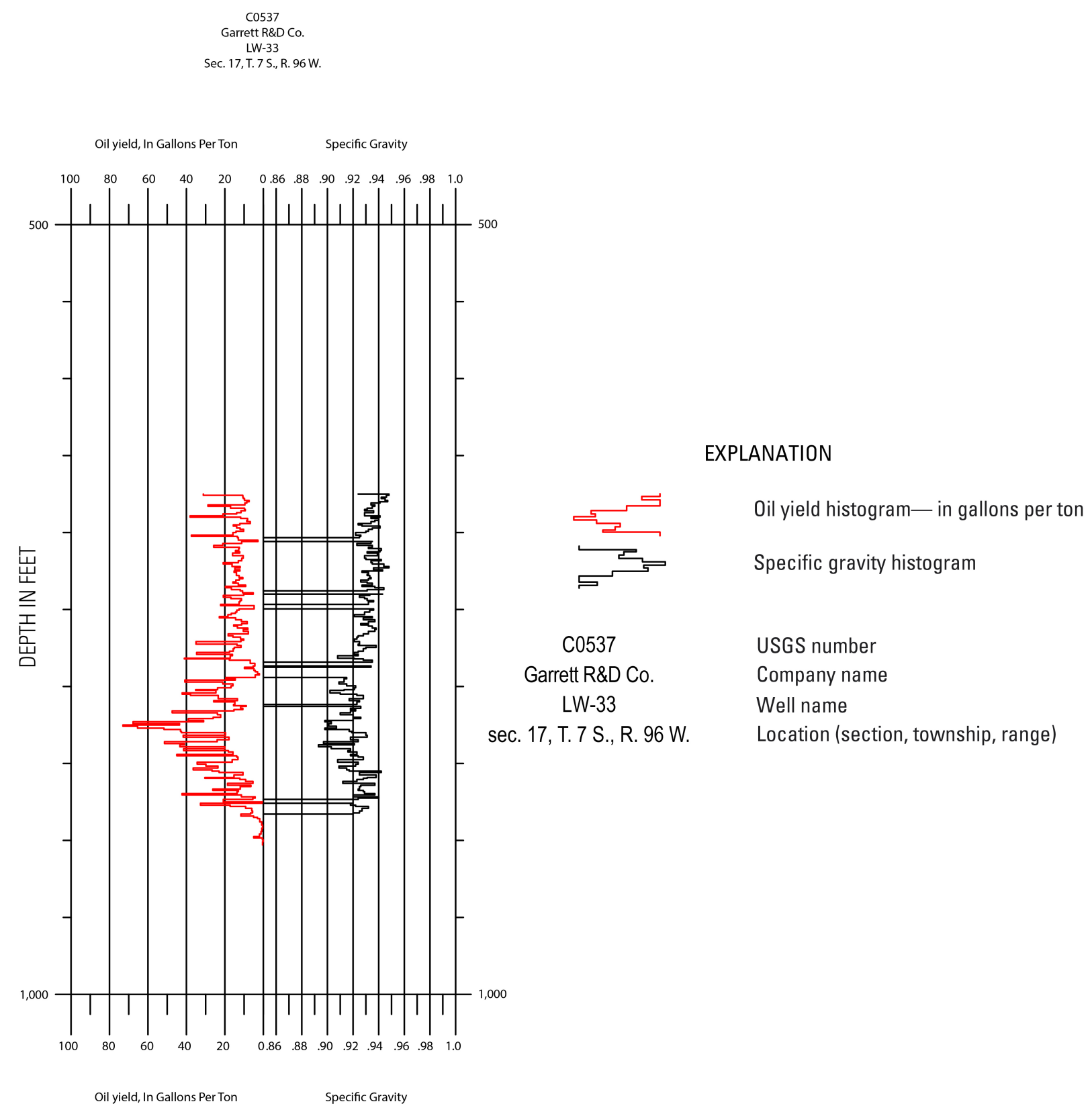

Figure 5. Example histogram plot showing Fischer assay oil yield in gallons per ton and oil specific gravity for borehole c0537 in the Piceance Basin, northwestern Colorado, plotted against depth. 


\section{Tables}

Table 1. Boreholes and stratigraphic tops in the Piceance Basin, northwestern Colorado.

[link; also available on CD-ROM]

Table 2. Names and definitions for the column headers for the Colorado oil-shale borehole information spreadsheet (table_1_CO_Borehole.xls).

[Some column names within table 1 may end in "J", which indicates they originated from J. Dyni's original tops; USGS, U.S. Geological Survey; Wyo., Wyoming; ft, feet]

\begin{tabular}{|c|c|}
\hline Column name & Column definition \\
\hline USGSID & Unique ID assigned by staff geologist \\
\hline CMPNYPROJ & Name of the company or agency that drilled the borehole or project name \\
\hline NAME & Name of the borehole assigned by the company or agency that drilled it \\
\hline EASTWEST & Distance, in $\mathrm{ft}$, measured east or west from section line \\
\hline NORSOU & Distance, in $\mathrm{ft}$, measured north or south from section line \\
\hline QQ & Quarter-quarter section \\
\hline SEC & Section \\
\hline TWP & Township \\
\hline RNG & Range \\
\hline LATITUDE & Latitude, in decimal degrees, North American Datum 1927, software-calculated, original record \\
\hline LONGITUDE & $\begin{array}{l}\text { Longitude, in decimal degrees, North American Datum 1927, software-calculated, original } \\
\text { record }\end{array}$ \\
\hline X_CALC & $\begin{array}{l}\text { Latitude, in decimal degrees, North American Datum 1927, digitized, software-calculated, this } \\
\text { report }\end{array}$ \\
\hline Y_CALC & $\begin{array}{l}\text { Longitude, in decimal degrees, North American Datum 1927, digitized, software-calculated, } \\
\text { this report }\end{array}$ \\
\hline LOCSOURCE & $\begin{array}{l}\text { Source of the borehole location, usually from the Fischer assay file, geophysical log, lithologic } \\
\text { log, or survey. }\end{array}$ \\
\hline COUNTY & Name of county in Colorado \\
\hline VFT & $\begin{array}{l}\text { Borehole reference elevation from which downhole depths were measured: ground level (GL), } \\
\text { rotary (Kelly) bushing (KB), or rotary table, top of collar (TC), derrick floor (DF), drill pipe } \\
\text { collar (Col.), mine level (ML), top of drill collar (DC), mine floor (MF), or top of casing (Cg). }\end{array}$ \\
\hline COREDINTV & Depths, in $\mathrm{ft}$, of the sequence that was cored in the borehole \\
\hline ELEVSRC & $\begin{array}{l}\text { Source of elevation, usually from the Fischer assay file, geophysical log, lithologic log, or } \\
\text { survey }\end{array}$ \\
\hline TOTDEPTFT & Total depth of the borehole, in $\mathrm{ft}$ \\
\hline QUAD & Name of 7.5-minute USGS topographic map, borehole may or may not be shown on map \\
\hline ARCHIVED & Core archived yes or no \\
\hline
\end{tabular}


Table 2. Names and definitions for the column headers for the Colorado oil shale borehole information spreadsheet (table_1_CO_Borehole.xls).-Continued

\begin{tabular}{|c|c|}
\hline Column name & Column definition \\
\hline YRDRILLED & Year that the borehole was drilled \\
\hline LOCCORE & Physical location of the core from core hole, for example, USGS Core Research Center \\
\hline SHOWNMAP & Indicates whether the actual borehole location is shown on the topographic map \\
\hline LITHFT & $\begin{array}{l}\text { Top and bottom borehole depths, in ft, of sequence of core or rotary cuttings for which a } \\
\text { lithologic log was prepared. }\end{array}$ \\
\hline PHOTOFT & Top and bottom borehole depths, in $\mathrm{ft}$, of photographic record of drill core \\
\hline ELECFT & Top and bottom depths, in $\mathrm{ft}$, of electric log of borehole \\
\hline GAMMAFT & Top and bottom depths, in $\mathrm{ft}$, of gamma ray log of borehole \\
\hline DENSFT & Top and bottom depths, in ft, of density log of borehole \\
\hline SONICFT & Top and bottom depths, in $\mathrm{ft}$, of sonic log of borehole \\
\hline NEUTRONFT & Top and bottom depths, in $\mathrm{ft}$, of neutron log of borehole \\
\hline CALIPERFT & Top and bottom depths, in ft, of caliper log of borehole \\
\hline RQDFT & Top and bottom borehole depths, in $\mathrm{ft}$, of rock quality data $\log$ \\
\hline TEMPFT & Top and bottom depths, in ft, of temperature log of borehole \\
\hline OTHERLOGS & Top and bottom depths, in ft, of other geophysical logs \\
\hline FISCHASSY & Top and bottom depths, in ft, of sequence analyzed by Fischer assays \\
\hline LAB & Name of laboratory where Fischer assays were performed \\
\hline ALUMINAFT & Top and bottom depths, in $\mathrm{ft}$, of sequence analyzed for alumina \\
\hline NUMBASSYS & Number of Fischer assays that were made \\
\hline USBMNUMBR & $\begin{array}{l}\text { Lab number assigned to the report of Fischer assays made by the former U.S. Bureau of Mines, } \\
\text { Laramie, Wyo. }\end{array}$ \\
\hline LOCATNOTE & Additional information, commonly used where there is a problem with the location \\
\hline NAHCOLTFT & Top and bottom depths, in ft, of sequence analyzed for nahcolite \\
\hline XRDFT & Number of X-ray diffraction analyses made on samples from the borehole \\
\hline ELEVNOTE & Additional information, commonly used where there is a problem with the elevation \\
\hline MISCNOTE & Miscellaneous information, such as publications related to the borehole, and other data \\
\hline REVISDATE & Date of last revision for original borehole data \\
\hline USGSID & Unique drill-hole number assigned by the USGS \\
\hline LABNO & U.S. Bureau of Mines, Laramie, Wyo., laboratory number \\
\hline TOPFT & Depth, in $\mathrm{ft}$, measured from surface datum to top of sampled interval \\
\hline
\end{tabular}


Table 2. Names and definitions for the column headers for the Colorado oil shale borehole information spreadsheet (table_1_CO_Borehole.xls).-Continued

\begin{tabular}{ll}
\hline \multicolumn{1}{c}{ Column name } & \multicolumn{1}{c}{ Column definition } \\
\hline BOTFT & Depth, in ft, measured from surface datum to base of sampled interval \\
SHLOILPCT & Amount of shale oil in weight percent \\
WATERPCT & Amount of water in weight percent \\
SHLRSDPCT & Amount of shale residue in weight percent \\
GASPLSPCT & Amount of "gas plus loss" in weight percent \\
OILGPT & Shale oil, in U.S. gallons per short ton of rock \\
WTRGPT & Water, in U.S. gallons per short ton of rock \\
SPCFGRAV & Specific gravity of shale oil \\
COKETEND & Tendency for spent shale to coke \\
\hline
\end{tabular}

Table 3. Names and definitions for the column headers for the Fischer assay data spreadsheets (for example, CO_Oil_Shale_Data_1-100.xls).

[USGS, U.S. Geological Survey; Wyo., Wyoming; ft, feet]

\begin{tabular}{ll}
\hline \multicolumn{1}{c}{ Column name } & \multicolumn{1}{c}{ Column definition } \\
\hline USGSID & Unique drill-hole number assigned by the USGS \\
LABNO & U.S. Bureau of Mines Laramie, Wyo., laboratory number \\
TOPFT & Depth, in ft, measured from surface datum to top of sampled interval \\
BOTFT & Depth, in ft, measured from surface datum to base of sampled interval \\
SHLOILPCT & Amount of shale oil in weight percent \\
WATERPCT & Amount of water in weight percent \\
SHLRSDPCT & Amount of shale residue in weight percent \\
GASPLSPCT & Amount of "gas plus loss" in weight percent \\
OILGPT & Shale oil, in U.S. gallons per short ton of rock \\
WTRGPT & Water, in U.S. gallons per short ton of rock \\
SPCFGRAV & Specific gravity of shale oil \\
COKETEND & Tendency for spent shale to coke \\
\hline &
\end{tabular}

